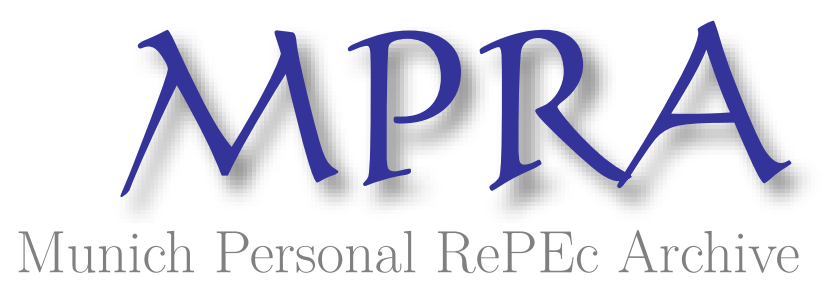

\title{
Vertical Intra-Industry Trade, Technology and Income Distribution: A Panel Data Analysis of EU Trade with Central-East European Countries
}

\author{
Gabrisch, Hubert \\ Halle Institute for Economic Research (IWH)
}

2009

Online at https://mpra.ub.uni-muenchen.de/64181/

MPRA Paper No. 64181, posted 24 Jun 2015 00:32 UTC 


\title{
VERTICAL INTRA-INDUSTRY TRADE, TECHNOLOGY AND INCOME DISTRIBUTION: A PANEL DATA ANALYSIS OF EU TRADE WITH CENTRAL-EAST EUROPEAN COUNTRIES
}

\author{
H. GABRISCH \\ (Received: 8 July 2008; revision received: 23 October 2008; \\ accepted: December 2008)
}

This paper tests a neo-Heckscher-Ohlin framework versus a neo-Ricardian framework for explaining vertical intraindustry trade. The study applies panel techniques with instrument variables to analyse trade between 'old' EU and 10 Central-East European countries in their post-transition period. Results show country-pair fixed effects to be of high relevance for explaining vertical intra-industry trade. Technology differences are positively, while differences in factor endowment measured in GDP per capita, are negatively correlated with vertical intra-industry trade, and confirm the relevance of the neo-Ricardian approach. In addition, changing bilateral differences in personal income distribution during the transition of Central-East European countries towards a market economy contribute to changes in vertical intra-industry trade.

Keywords: Trade theory, vertical intra-industry trade, EU trade, Central-East European countries

JEL classification index: F14, F15

\section{Short title: EU trade with CEE countries}

| Corresponding address: H. Gabrisch, IWH (Halle Institute for Economic Research), Kleine Märkerstr. 8, Halle (Saale), D-06108 Germany. E-mail: gab@iwh-halle.de 


\section{INTRODUCTION}

This paper asks why product differentiation is predominant between high and low quality varieties of the same goods in trade between the 'old' EU-15 and ten Central-East European countries (CEEC-10) ${ }^{1}$. Although this study does not explicitly discuss policy issues, its results may implicitly add to political considerations. For example, intra-industry trade is commonly related to the 'smooth labour market adjustment hypothesis', which states that workers of a given industry may find a job more easily at another company of the same industry when international competition is within and not between industries. However, vertical intra-industry trade challenges this hypothesis, for the technologies and skills that produce similar goods differ may not suffice to find a job at another firm producing a similar kind of goods, but with different technology. Another example is personal income distribution. In intra-industry trade models inequality in personal income distribution is disregarded; but in vertical trade models income distribution plays a leading explanatory role as an explanatory argument, thus policy with its distributional effects comes into play.

Trade relations between the two groups of countries - the CEECs being former socialist countries - are characterised by fast track of regional integration and short geographical distances, which is in contrast with trade relations dealt with in most other empirical studies. However, intra-industry trade relations between the two groups of countries have been given relatively little attention by trade economists. In the 1990s, a considerable number of works concentrated on the measurement of changes in the trade structures (Landesmann 1993, Landesmann and Burgstaller 1997, Rosati 1998, Fidrmuc 2000), not at least due to a flawed data base, which might have biased testing models. The first analytical papers emerged in the second half of the 1990s, with an industry-specific approach (Djankov and Hoekman 1996, Thom and McDowell 1998, Aturupane et al. 1999, Ando and Kimura 2005). In classical trade economics country-specific determinants matter, to which firms adjust. Industry-specific approaches stem from attempts of the 'new trade theory' to expand the classical trade theory by, for example, product differentiation behaviour of firms on the background of firm- or industry-specific determinants like fragmentation of production chains, or related foreign direct investment. Empirical literature has found more support for country rather than industry determinants. And even, when cross-border production sharing explains the strong increase in vertical intra-industry 
trade (Ando 2006), it remains unclear whether multinational companies follow rather countryspecific determinants after lifting trade barriers, or does international fragmentation stem from industry specifics.

There were only few papers on intra-industry trade relations of the former socialist countries from the country-specifics perspective, most of them since the year 2000 (Gabrisch and Segnana 2002, and Gaetano and Galego 2007 for European transition countries, or Zhang et al. 2005 for China). While Fidrmuc et al. (1999) examined the relationship between intra-industry trade and trade liberalisation for this region, the following research focused on two sets of variables, which are of specific interest for the current study. The first set of variables includes relative factor endowment and/or differences in technology. Factor endowment and/or technology differences between the EU and CEECs became visible after the opening of the economy and the imposing of free trade agreements in bilateral trade. Different from most other researches we try to clearly distinguish between cost and quality determinants. The second one captures differences in income distribution. The paper does not treat income distribution as a time-invariant variable. Rather, it is the change of differences between countries that is considered, not least, since CEECs experienced major changes in their income distribution towards more inequality (and back) during their transition from socialist to market economies.

The remainder of this study includes four sections: Section 1 discusses the position of technology and capital/labour ratios, and income distribution in the theory of intra-industry trade and open questions in theoretical and of empirical research. Section 2 presents the empirical approach including equations to be tested, variables and data. Section 3 reports the findings, and section 4 provides conclusions and some policy-oriented hypotheses for further research.

\section{COST AND TECHNOLOGY ADVANTAGES, AND INCOME DISTRIBUTION IN THE THEORY AND EMPIRICISM OF INTRA-INDUSTRY TRADE}

Income distribution within each country and differences in technology do not matter in firstgeneration models of intra-industry trade (see above all Helpman 1987, and Hummels' and Levinsohn's empirical 1995 study). The intra-industry shares of bilateral trade increase with rising similarity of countries by size, and declines with rising differences in capital/labour ratios. The latter explains the inter-industry trade component in total trade. The models assume that 
households in two countries consume all varieties of differentiated goods of the same quality. In empirical research, GDP differences represent the similarity by size, which stands for similar consumer tastes and serves as an argument for horizontal trade patterns. The GDP per capita (or worker) stands for different capital/labour ratios. A capital abundant country is thought to pay higher wages than a labour abundant country. While empirical estimations confirmed the positive impact of size similarity on intra-industry trade share, Hummels and Levinsohn (1995) revealed a negative sign of the relative GDP per capita in pooled OLS estimations as predicted. However, when panel estimations with fixed effects were used in order to 'clear' the error term from truly idiosyncratic errors, the sign turned positive. The authors explained this change with country-pair specific effects like distance and land to labour ratios, which are beyond the theory of intraindustry trade. Durkin and Krygier (2000) challenged this conclusion, pointing at the possibility that intra-industry trade is not overwhelmingly horizontal but vertical, and thus the GDP per capita variable can obtain a positive sign in a specific theory of vertical intra-industry trade. This specific theory also has close relations to an increasing number of studies that revealed the important role that quality plays as a determinant of the global patterns of bilateral trade (Schott 2004; Hallak 2005).

In contrast to first-generation models, vertical intra-industry trade models necessarily assume that each household consumes only one variety of goods, which is differentiated according to quality. Therefore, income distribution within a country matters with respect to the combination of varieties consumed by that nation. With rising differences in income distribution, the models predict the vertical intra-industry share to rise. Empirical research seems to have confirmed this relationship. ${ }^{2}$ However, two problems appear with these studies: (i) Inequality in income distribution is treated as a time-invariant country-pair specific effect in most research (Durkin - Krygier 2000; Martin-Montaner - Orts Ríos 2002 (missing from the referenesxxx), Zhang et al. 2005). The argument is that income distribution tends to remain stable over time. In a larger time horizon, this treatment is not plausible at least for European transition countries where inequality increased quickly in the first stage of their transition (Milanovic 1998; Aghion Commander 1999). (ii) A second problem is endogenity: income distribution is expected to explain vertical intra-industry trade, but the lifting of trade barriers may also induce changes in income distribution, a phenomenon addressed also in some literature on economic relations between EU and CEE countries (for example, Lorentowicz et al. 2005, or Goh - Smarszynska- 
Javorcik 2005). ${ }^{3}$ Not to mention that the endogenity problem might be worse in case of timevariant income distribution.

Existing empirical research focuses on the structures of the production side, since the household side is not sufficient to explain, which of the varieties is produced in each of the trading countries. Borrowing from the traditional trade theory, vertical intra-industry trade models split into neo-Heckscher-Ohlin (neo-OH) and neo-Ricardian approaches. In empirical neo-HO models, the GDP per capita stands for capital/labour ratio but, in contrast to the firstgeneration theory, a positive correlation to intra-industry trade is predicted. However, when total trade includes vertical intra-industry trade and inter-industry trade, factor proportions cannot explain both. Falvey - Kierzkowski (1987) solved the problem at the theoretical level. In their model, inter-industry trade occurs by the exchange of homogeneous with differentiated goods. Homogeneous goods are produced with one single input factor and the technological advantage of one of the trading countries in its labour input function. Differentiated goods are produced according to capital/labour ratios. Consequently, technology is negatively and capital/labour ratios are positively correlated with vertical trade, and vice versa with inter-industry trade. Most of the recent empirical studies test the relevance of a neo-HO framework with factor endowment differences among countries (see, for example, Mora 2002; Martin-Montaner and-_Orts Ríos $2002 \mathrm{xxx}$ ) and to find evidence for this approach. ${ }^{4}$ Milgram-Baleix and Moro-Egido (2006) treat technology not as a Ricardian, but as one of factor endowment variables, an attempt that might blur the differences between the theories. Here, one might find the reasons why variables do not show the expected signs.

A plausibility problem with the neo-HO approach is that the relative price of each variety of differentiated goods is driven by relative costs. Hence, quality differences reflect cost differences, an assumption which hardly seems to have 'the right feel' (Krugman 1986, p. 37). Simply put, if one wants to have both vertical intra-industry trade and factor endowment, one might be forced to make appropriate but implausible assumptions. The neo-Ricardian model of vertical intra-industry trade, which Flam - Helpman (1987) developed, might be a good candidate to solve this problem. With one factor input (labour) only, differences in technology explain one country's advantage in producing a higher quality of differentiated goods. With monopolistic competition, quality differences are reflected in price and wage differences. In this model, there is no room for factor endowment differences. An improvement in technology in the home country improves the advantage to this country in producing a high quality variety and raises the price of 
that variety as well as the wage rate in producing it. A change in the relative price of differentiated goods sets incentives for the reallocation of production: more labour will be used for the high-quality variety in the home country and for the low-quality variety in the foreign country. The appealing feature of this model is that it explains a product-quality cycle in which the less developed country begins to produce varieties that were produced in the advanced country, after the latter has started to produce new varieties at a higher quality level. ${ }^{5}$ This cycle opens the option that firms in the technologically advanced country can concentrate on the highquality varieties after the technological innovation is accomplished, and shift production of the varieties with outdated technology to the backward country. To put it differently: upgrading in terms of technology is possible, but not catching up, and this might shed new light on the foreign direction for such behaviour can be found in the fragmentation literature. This perspective is not contained in the Falvey-Kierzkowski model, for technology matters in producing homogeneous goods. Durkin and Krygier (2000) tested the Flam-Helpman model for US trade with other OECD countries, treating, however, the GDP per capita variable as an expression for technology differences. They found the expected positive correlations between GDP per capita and vertical intra-industry trade. But it remains unclear what their test really revealed: for the positive correlation between GDP per capita and vertical intra-industry share might stand for a neo-HO interpretation or for a Ricardian framework. Hence, to find an answer to this crucial question, a specific technology variable should be included in the list of explanatory variables. It might help to find out whether EU-CEEC trade relations are driven by a product-quality cycle or not. Furthermore, any empirical test of trade structures should address the endogenity problem.

\section{EMPIRICAL METHODOLOGY}

Testing equations: We test a static vertical intra-industry trade model and apply specifications with pooled and panel data (the latter including fixed and random effects estimators). Equation (1) presents the complete model in the pooled version with all variables:

$$
\begin{aligned}
& \operatorname{VIIT}_{j k, t}=\beta_{0}+\beta_{1} R_{E L G D P C}{ }_{j k, t}+\beta_{2} \text { RELTECH }_{j k, t}+\beta_{3} \text { RELINDIS }_{j k, t}+\beta_{4} \text { MINSIZE }_{j k, t}+ \\
& \beta_{5} M_{A X S I Z E} E_{j k, t}+\beta_{6} D I S T A N C E+\beta_{7} C U D U M_{j k, t}+\mu_{j k, t}
\end{aligned}
$$


VIIT $_{\mathrm{jk}, \mathrm{t}}$ is the vertical intra-industry index in trade of the reporting EU country $j$ with its partner country $k$ at time $t$. Since indices are between $[0,1]$, we use logistic transformations for VIIT, while explanatory variables are in logarithmic expressions. $\mu$ is the error term. The first explanatory variable measures the difference in the GDP per capita between both countries. RELTECH measures for differences in the endowment with technology. RELINDIS stands for differences in income distribution. The MIN and MAX variables represent size differences in terms of total GDP, and they stand for the similarity of consumer tastes and the power of HIIT. MINSIZE $_{\mathrm{j}}$ (MAXSIZE) selects the lower (larger) GDP from a pair of countries. DISTANCE is a representative for transaction costs of trade, which increases with a larger geographical distance. It brings the model closer to gravity models of trade. All pooled specifications include a liberalisation dummy, which captures the membership of a member in the EU customs union (CUDUM). ${ }^{6}$ If a CEE country is a member of the union, the dummy receives the value 1 (which applies to eight of the ten countries for 2004, Bulgaria and Romania excepted). In all other cases, the dummy receives the value 0 .

A first problem is that the REL-variables are endogenously determined by VIIT. If endogeneity is present, then OLS estimates will be biased and inconsistent. To test this hypothesis, we need to find a set of instrumental variables that are correlated with the suspect REL-variable but not with the error term of the VIIT equation. However, the cost of using TSLS is a scaling down in the number of observations. A second problem might be multicollinearity between REL-variables. We are concerned that the applied range of technologies is correlated with the GDP per capita, and regressions might result in unreliable coefficient estimates. Therefore, we prefer to run regressions, which include only one of both variables.

Pooled regressions produce a common constant for all country-pairs. At first glance, this seems to be the appropriate specification, since bilateral trade agreements between the EU and CEECs are identical, for trade policy is a matter for the EU authorities and not of single member countries. However, one cannot exclude that apart from general trade rules of the EU, bilateral trade relations are ruled by other specifics, including non-economic ones. For example, border trade regimes (Germany-Poland, Austria-Hungary, Italy-Slovenia) might exert a certain impact on bilateral trade compared to other country pairs (France-Poland, Belgium-Slovenia). Further, different regimes of factor movement (capital, labour) might affect bilateral trade. And in pooled regressions, the error term might include time-invariant effects beyond the distance variable such as cultural differences between country pairs. Indeed, the friendly relations between Austria and 
Hungary in their common history (until 1918) might influence trade patterns - a factor that certainly has no effect in Ireland-Hungary relations. Therefore, we complete pooled regressions by the application of panel techniques with fixed effects (FE) and random effects (RE) specification. Finally, with OLS we assume a constant variance in the error term. In samples with very large differences in country pairs, such as Germany-Slovenia compared to Austria-Slovenia, we might meet with heteroscedasticity. Indeed, specifications with cross-section weights produce higher t-values, and we cannot assume constant variances to be appropriate.

Predictions on signs: In first generation models of (horizontal) intra-industry trade, the RELGDPC variable explains (with a negative sign) the inter-industry trade component of total trade. In a (second generation) model of vertically dominated trade, this variable should appear with a positive sign, when it explains differences in capital/labour ratios, and the RELTECH variable should obtain a negative sign. If VIIT were driven by technology differences (the neoRicardian model), we should obtain the opposite signs in both variables. The coefficient to RELINDIS should be positive in both cases, supposed we applied a meaningful method of disentangling vertical and horizontal trade.

The first-generation theory of intra-industry trade predicts a positive (negative) sign for MINSIZE (MAXSIZE), since size stands for similarity and common consumer tastes. ${ }^{7}$ Vertical intra-industry trade theory does not clearly predict the signs for size variables. Durkin and Krygier (2000) found the opposite behaviour of the variables in total IIT, VIIT and HIIT estimations. The expected sign for DISTANCE is negative for all IIT specifications, for the relevance of transaction costs in trade with differentiated goods is higher compared to interindustry trade with homogeneous goods. The predicted sign of the customs union dummy (CUDUM) is negative for all specifications, for lifting trade barriers diminishes trade costs.

Finally, we run the same models for HIIT specifications in order to check VIIT results for robustness. If the VIIT variables do not explain HIIT, all the REL-variables should obtain negative signs.

Calculation of variables. Methodological issues: Since data on income distribution is the limiting factor in comparative research, and allows for only three years' observations in this study, we calculated the trade variable for the years $1993,{ }^{8} 2000$ and 2004 . We start with 1993 , when East European countries were still at an early stage of systemic transition. In this year, European agreements started gradually to impose a free trade zone between the EU and transition countries, which would end with their accession to the Union and the customs union. In May 
2004, eight of the ten countries became members of the EU, Bulgaria and Romania being the exceptions. We calculated country-pair indices for all variables for a matrix with $\mathrm{m}=14 \mathrm{EU}$ countries (excluding Luxembourg) and $n=10$ CEECs, and received 140 observations per year, and 420 for three years. However, applying TSLS will scale down the number of observations to 280. The time span left (1993 to 2000) seems still wide enough to run FE models.

IIT, VIIT, HIIT: Intra-industry trade shares of total trade are calculated by applying the GrubelLloyd (GL) index on 778 industries (4-digit level) of chapters 3 to 8 (manufacturing industries) of the Combined Nomenclature from Eurostat. The various problems with that statistical approach, including the disaggregation biases are addressed in the $\underline{a}$ Appendix. There are various proposals to disentangle both components, vertical and horizontal intra-industry trade. With reference to the empirical literature, which founds that unit values vary with 'exporter production techniques' (Schott 2004), we followed the standard approach using unit values in exports and imports. An item belongs to the vertical part, if the relative unit value (RUV) exceeds or falls below a certain threshold. We calculated VIIT figures using a threshold of \pm 15 from unit. This threshold has been often used in similar research (for example, Abd-el-Rahman 1984, Aturupane et al. 1999, Caetano and Galego 2007). The size of the threshold is subject to debates in the literature. We believe that the chosen threshold ensures a good cut between vertical and horizontal trade relations (see also the aAppendix).

Figure 1 provides the descriptive statistics for $(140 \times 3=420)$ country-pair GL-indices of total intra-industry trade. With trade liberalised step by step from 1993, the unweighted ${ }^{9}$ mean bilateral intra-industry share of total trade between the EU and CEE-10 rose from a mere 13 per cent on average to 21 per cent in 2004 . Nevertheless, trade between the two regions is overwhelmingly inter-industry. The standard deviations indicate a high variance, which is a good pre-requisite for efficient regression results. For example, intra-industry trade shares were between 67 per cent (Germany-Czech Republic) and 1 per cent for (Portugal-Latvia) in 2004. However, Figure 2 shows that intra-industry trade is vertically dominated, if calculated with a $15 \%$ threshold. The mean values are well above 80 per cent of intra-industry trade, although they decreased somewhat throughout the period.

Often, vertical intra-industry indices are split into high-quality and low-quality components. From the theoretical perspective such a de-composition is not necessary, for vertical and high- 
quality vertical intra-industry trade models include the same set of (factor endowment) variables. From the empirical point of view, there is no need for running regressions for each component. The rationale of presenting this split here is to show that there might be a product-quality cycle in trade relations. As Figure 3 depicts, most country-pairs include a quality advantage of the EU country, although somewhat eroding.

Figure 3

Factor endowment and technology differences: The widespread used indicator for factor endowment differences is the relative GDP per capita, here calculated as $\left(G D P C C_{j, t}\right.$ minus $\left.G D P C_{k, t}\right)^{10}$ at current exchange rates. The data is in Euro and is taken from Eurostat Online Database (2005b). With respect to the relative position in technology, the study uses data on the number of firms applying leading technology and of firms with low technology for each country (Eurostat Online Database 2006). We decided to choose this indicator in order to obtain a picture, which is independent of value calculations such as cost variables. ${ }^{11}$ We calculated the ratios of the numbers of leading to low technology firms for each country and took the absolute difference between two countries. The indicator can take values between 0 and 1 . The higher the value is the larger is the technology difference.

Income distribution: The country-pair observations of (changes of) differences in income inequality are calculated according to the overlap concept, which Flam and Helpman (1987) directly derived from theory. The overlap income distribution argument is

(2) $I D_{j-k}=\frac{F_{j}\left(h_{d, j}\right)}{1-F_{k}\left(h_{d, k}\right)}$

$F_{j, k}($.$) are the cumulative distribution functions f$ in country $j$ (EU) and $k$ (CEEC) up to the household $h$ with the dividing (or marginal) income level $d$, which is in the interval $h j, k=\left[0, \ldots h_{j, d}, h_{k, d}, \ldots 1\right]$. Households with an income less than $h_{d}$ consume the low-quality variety of differentiated products, and households with a higher income consume the high-quality variety. Any change in the cumulative distribution functions is positively correlated with vertical intraindustry trade. There are some significant differences to the empirical overlap concept, Durkin and Krygier (2000) used. Firstly, this study is based on deciles and not quintiles. Secondly, the 
larger income differences between EU and CEE countries compared to the US-OECD framework in Durkin and Krygier, requires a more sophisticated method of calculation of the dividing income class. ${ }^{12} \mathrm{We}$ assume the dividing income class in the framework $j-k$ to be around the bilateral average GDP per capita of both countries. GDP data for 1993, 2000 and 2004 are from Eurostat Online Database (2005b). The variable for a single country-pair is constructed according to

$$
\text { (3) } \quad R E L I N D I S_{j k, t}=\ln \left|F_{j}\left(h_{d, j-k}\right)-\left(1-F_{k}\left(h_{d, j-k}\right)\right)\right|
$$

This study uses personal income distribution, for it captures not only changes in the relation of market wages and market profits, but also redistribution from tax policy and changes in the social system. The concept assumes a dividing income class in each national economy. Income distribution data is taken from World Income Inequality Database (UNU/WIDER 2005).

Table 1 provides the descriptive statistics of the REL-variables in their original values. High standard deviations and large country differences suggest the application of fixed effects estimators, and let expect significant coefficients in regressions. For example, the highest bilateral difference in GDP per capita was Ireland-Bulgaria with 24,100 Euros in 2004, following 8,700 Euros in 1993 and 20,100 in 2000. With respect to RELTECH, mean values suggest a fall in technology differences, and the standard deviation shows some convergence among countrypairs. In income distribution, the first impression is a declining difference in country-pair income distribution between EU and CEECs. This general decline seems to reflect the reaction of policy to the increasing poverty ratios among the populations of transition countries. The largest bilateral difference was between Germany and Romania, and the lowest difference was between Denmark and Poland in the third year of observation.

Table 1

Other variables: (MINSIZE ${ }_{\mathrm{j}}$ (MAXSIZE) selects the lower (larger) GDP in Euro in current exchange rates from a pair of countries. In most, but not all, cases MINSIZE stands for the CEE country and MAXSIZE for the EU country. ${ }^{13}$ DISTANCE is measured in kilometres between the capitals of both countries. 


\section{ESTIMATION RESULTS}

Columns (1) throughout (6) of Table 2 show the results according to the three model specifications (pooled, fixed and random effects) for vertical intra-industry trade. The explanatory power $\left(\mathrm{R}^{2}\right)$ in pooled and fixed effects models is high enough to assume that intraindustry trade is not a pure statistical phenomenon due to inappropriate calculations. The FE model in (3) and (4) is superior to the pooled specification in (1) and (2) since sum squared residuals are lower. Nevertheless, the regressions with pooled data present the important information that distance and being a member of customs union obtain the expected negative signs both regressions (but, DISTANCE is insignificant in the second model). We find FE to be highly significant. ${ }^{14}$ The explanatory power improves significantly compared to pooled regressions, which means that country-pair effects have a relevant impact on vertical trade patterns. The Hausman test shows that the RE model in (6) is not appropriate. In (5) the Chisquared statistics is close to the $10 \%$ level of significance, but the sum squared residuals are still above those of the respective FE specification in (3). Hence, we do not take the Hausman test too literally and assume the FE specification as appropriate.

For FE specifications the income distribution variable obtains the predicted positive sign: with higher bilateral difference in income distribution, the share of VIIT in total trade increases. Comparing (3) and (4), we are also able to conclude that differences in technology (RELTECH) are the driving force in EU-CEEC trade structures, while differences in factor endowment (RELGDPC) are not. RELGDPC appears with a negative sign, and we may reject the neo-HO hypothesis of VIIT. ${ }^{15}$ This negative sign contradicts to most other literature on vertical intraindustry trade (see section 1). An exception are Caetano and Galego (2007), who found also a negative sign for the relative GDP per capita variable, and positive signs for Foreign Direct Investment and human capital investment (which could be seen as other versions of our technology variable). Both authors calculated the IIT shares according to Fontagnè - Freudenberg (1997), who identified trade as intra-industry, if the minority trade flow is at least $10 \%$ of the majority trade flow. With respect to the size variables, we cannot confirm the findings of Durkin - Krygier (2000). In (3), we find a negative impact on VIIT if an EU country was significantly 
larger than the less advanced CEE country (MAXSIZE). On the other side, a positive impact on VIIT appeared when the less developed CEE country was significantly smaller than the EU country. In (4), the composition of signs changed. OLS estimations (Appendix Table. A1), the superiority of the FE model is clearer than in IV-estimations. All SIZE-variables have a positive sign. However, RELGDP and RELTECH have the same signs, and an interpretation, which model is superior, is not possible.

The results of estimations with instruments contradict also a recent study by Milgram-Baleix and Moro-Egido (2006) who explicitly attempt to test the neo-HO framework against the neoRicardian framework using Spanish data. In their model, the capital intensity variables bear a positive sign, while differences in technological capital receive a negative sign. The reason might be that the model specifications do not clearly discriminate between endowment differences and technology differences. Another problem is possibly collinearity between variables like physical capital endowment and technology capital. Nevertheless, the authors conclude that their test results confirm rather the neo-Ricardian perspective.

Table 3 reports the results for the same variables in a HIIT specification. Again, we find distance and becoming a customs union member to have the predicted signs in pooled regressions, when they are significant. But, we find now the FE model not to be appropriate compared to the RE model, since the insignificant chi-square statistics reveals correlation of the error term with independent variables. However, results and quality of the model illustrate that the HIIT model is 'misspecified': the VIIT variables do not explain horizontal trade structures. The explanatory power is rather low. All REL-variables are negative in RE estimations; hence, they play no role in explaining horizontal intra-industry trade. We take this result as a further, indirect confirmation of the VIIT model. The size variables took the signs predicted by theory for horizontal trade only in the FE specifications. Regressions with OLS suggest the FE specifications; here the wrong (negative) sign for income distribution confirms that income distribution does not explain horizontal, but vertical trade only. In general, the findings are in line with the estimation results Hummels and Levinsohn (1995) obtained for total intra-industry trade in a first-generation approach. 


\section{CONCLUSIONS}

Our objective was to explain vertical intra-industry trade between old and new EU countries either by differences in factor endowment or in technology, and to specify the role of changing income distribution of former socialist countries during their transition toward a market economy. With respect to our starting position, we believe that the results contribute some progressive insights to the literature:

The first conclusion is about the driving force of production localisation in the regional framework considered: costs or technology? We made it possible to disentangle both determinants, backed by different theories. Estimations tend to produce a significant positive correlation between technology differences and vertical trade. A negative correlation was found between GDP per capita differences, which are usually seen as proxy for factor endowment differences, and vertical trade. Therefore, there is some indication of a product-quality cycle in EU-CEEC relations; upgrading in terms of technology seems very realistic, but catching-up scenarios should be viewed with caution. Obviously, such a statement would include the contribution of foreign direct investment in structural change and growth in former transition countries. An issue for further research might be to test the cycle view by an analysis of crossborder production sharing, where $R \& D$ activities and the high-quality production remain in the headquarter of the developed country, and assembly plants are located in the poorer countries. Ando - Kimura (2005) found evidence for such a cross-border fragmentation in trade data of Japan with the CEECs. Another issue for further research might be to check whether our results are due to some noise in the vertical intra-industry determinant. It cannot be ignored that at the 4digit level of trade, the variables might be still contaminated with a good portion of inter-industry elements, although $\mathrm{R}^{2} \mathrm{~s}$ in regressions were high enough to exclude results being purely accidental. Our decomposition of vertical trade disregards extreme price differences in exports and imports due to, for example, transfer pricing and related behaviour of firms (see Gabrisch Szalai 2002, for an approach to use unit values in estimating the size of such behaviour). Also, a Neo-Heckscher-Ohlin or Neo-Ricardian approach can hardly capture such phenomena in trade like international production sharing; back-and-forth transactions are hardly to reconcile with a quality ladder. There is some recent research on that issue (Ando 2006).

Changes in personal income distribution seem to play a role for changing trade patterns. This brings us to the second conclusion that the distributional effects of policies matter. When we 
assume that horizontal trade patterns are based on similar income distribution, a government might influence the shift to a more horizontal pattern by considering the distributional effects of its policies. In CEECs, income distribution shifted towards more inequality in their early transition period, and might have contributed to the high vertical shares in trade. But later we observe a correction towards more equality, which seems to have been a reason for the falling vertical and increasing horizontal shares in trade. Further research should compare both regions of the enlarged Union individually in order to find out whether income distribution schemes tend to converge or diverge, and whether this has an impact on trade patterns.

\section{APPENDIX}

\section{Grubel-Lloyd index}

In equation (2), $T_{j k}$ is the intra-industry share in total trade between a pair of countries $j$ (home) and $k$ (foreign), and for a set of $n$ industries with $X$ being the exports of the home country and $M$ being its imports from the foreign country in the individual industry $i$ :

$$
T_{j k}=\frac{\sum_{i=1}^{n}\left(X_{j}^{i}+M_{k}^{i}\right)-\sum_{i=1}^{n} \mid\left(X_{j}^{i}-M_{k}^{i}\right)}{\sum_{i=1}^{n}\left(X_{j}^{k}+M_{k}^{i}\right)}
$$

The share of inter-industry trade in total trade is $\left(1-T_{j k}\right)$. Although the prescription for calculation makes a sharp cut between inter- and intra-industry trade, $T_{j k}$ is necessarily contaminated with some noise, for the data are for industries and not for individual goods. And here, disaggregating is relevant. With low-digit disaggregation (2-digit, for example), the index includes some inter-industry trade (Celi - Smith 1999). Therefore, a high-digit level is preferable for calculating the index. But with more disaggregated data, the number of empty entries in statistical reporting increases, and specific methods like the Heckman technique (see MilgramBaleix and Moro-Egido 2006) are needed to avoid biased estimation results. In order to mitigate the trade-off problem and keep the tools simple we decided to choose the 4-digit level. ${ }^{16}$ We pay particular attention to $\mathrm{R}^{2}$ of regressions in order to become certain that the chosen level is not too much distorted by inappropriate calculation. Furthermore, intra-industry trade models assume 
balanced total trade, and imbalances might distort the correct measurement of shares. However, the empirical literature has not confirmed the superiority of the trade-balance adjusted GL index, and we use the unadjusted index in regressions. ${ }^{17}$ Fontagné - Freudenberg (1997) suggested an approach as alternative to the overlap concept of Grubel - Lloyd, defining all products as of the intra-industry part where imports account for at least $10 \%$ of exports. Also, they found in their 2005 study $(2005$, p. 17) the results of both methods to be highly correlated. This conclusion seems to be confirmed by the comparison of our regression results with the results of Caetano Galego (2007), who used the method of Fontagné - Freudenberg.

\section{Disentangling horizontal and vertical trade}

Intra-industry trade concerning a specific kind of goods is horizontal when the prices of the exported and imported varieties are close to each other. Trade statistics aggregate similar goods to industries and similar industries to sectors, for which 'prices' exist only under very restrictive conditions (identical costs, for example). Unit values (in this study: trade value divided by metric tons) are the usual indicator used for identifying differences in price indices, and relative unit values (RUV) relate the unit values of export to those of imports. Intra-industry trade in a certain trade item is vertical when the relative unit values of exports and imports in the same industry are less than (1-a) and larger than $(1+a)$ with $a$ being the threshold:

$$
\begin{aligned}
& T_{V i i t, j k}=\sum_{p=1}^{m} t_{p, j, k} \text { for all items } p=1 \ldots . m, \text { which fulfil the condition: } \\
& (1-a)>\left(R U V_{i j k}=\frac{U V X_{i j k}}{U V M_{i j k}}\right)>(1+a)
\end{aligned}
$$

Within this range, trade is assumed to be horizontally differentiated, and outside of the range, equation 3 produces the share of vertical intra-industry trade. Those items with an RUV $>(1+a)$ yield a high-quality position in the EU's trade, and those with an RUV $<(1-a)$ yield a low-quality position. However, with respect to possibly large differences of RUV in trade of economically advanced countries with developing countries, Fontagné - Freudenberg $(1997,2005)$ argue to choose a higher threshold $(\mathrm{a}=0.25)$. The consequence would be to move a part of formerly identified vertical trade relations to the horizontal component. The relative weight of extreme RUVs in VIIT would increase. Although the algorithm ensures that all items beyond the 
threshold belong to vertical intra-industry trade, the results of such a statistical exercise should not be taken too literally. It is not very plausible to assume that two items with a price difference of more than $1,000 \%$ really stand for two varieties of the same goods and prices stand for quality differences.

\section{ACKNOWLEDGEMENTS}

A first and rather different version of this paper has been presented at a seminar at the University of Trento, 2004. The author gratefully acknowledges the comments made by two anonymous referees. Special thanks go to Harry Flam, who confirmed the author's conviction in an important theoretical issue, and to Maria-Luigia Segnana (Trento), who co-authored some earlier papers on EU-CEEC trade relations. Of course, the usual disclaimer applies.

\section{REFERENCES}

Abd-El-Rahman, K. (1984): Firms' competitive and national comparative advantage as joint determinants of trade composition. Weltwirtschaftliches Archiv, 127 (1): 83-97.

Aghion, P. - Commander, S. (1999): On the dynamics of inequality in the transition. Economics of Transition, 7(2): 275-298.

Ando, M. (2006): Fragmentation and vertical intra-industry trade in East Asia. North American Journal of Economics and Finance, 17: 257-281.

Ando, M. - Kimura. F. (2005): Fragmentation in Europe and East-Asia. Evidence from International Trade and FDI Data. Paper presented at the international conference "International Trade and Logistics, Corporate Strategies, and the Global Economy: European and East Asian Experiences" held at University of Le Havre, France, September 28-29, 2005. Available from http://www.univ-lehavre.fr/actu/itlcsge/ando.pdf

XXXX Author???Logisties, Corporate Strategies, and the Global Economy: European and East Asian Experiences" held at University of Le Havre, France on September 28-29, 2005.

Aturupane, C. - Djankov, S. - Hoeckman, B. (1999): Horizontal and vertical intra-industry trade between Eastern Europe and the European Union. Weltwirtschaftliches Archiv, 135 (1): 62-81.

Caetano, J. - Galego, A. (2007): In Search for the Determinants of the Intra-Industry Trade within an Enlarged Europe. South-Eastern Europe Journal of Economics, (5)2: 163-185.

Celi, G. - Smith, A. (1999): Quality differentiation and the labour market effects of international trade. CELPE Discussion Paper 49, University of Salerno.

Díaz Mora, C. (2002): The role of comparative advantage in trade within industries: a panel data approach for the European Union. Weltwirtschaftliches Archiv, 138 (2): 291-317.

Djankov, S. - Hoekman, B. (1996): Intra-industry trade, foreign direct investment and the reorientation of East European exports. CEPR Discussion Paper, No. 1377. London: Centre for Economic Policy Research.

Durkin, J. T. - Krygier, M. (2000): Differences in GDP per capita and the share of intraindustry trade: the role of vertically differentiated trade. Review of International Economics, (8)4: 760-774.

Eurostat online database (2005a): Available at Comext (http://epp.eurostat.cec.eu.int/portal/. 
Eurostat online database (2005b): Economy and Finance, National Accounts. Available at http://epp.eurostat.cec.eu.int/portal/.

Eurostat online database (2006): Economic statistics on High-tech Industries and Knowledge Intensive Services. Available at http://epp.eurostat.cec.eu.int/portal/.

Falvey, R. E. - Kierzkowski, H. (1987): Product quality, intra-industry trade and (im)perfect competition. In: Kierzkowski, H. (ed): Protection and competition in international trade. Oxford: Basil Blackwell, pp. $142-61$.

Flam, H. - Helpman, E. (1987): Vertical product differentiation and North-South trade. American Economic Review, (76)5: 810-822.

Fidrmuc, J. (2000): Restructuring European Union trade with Central and East European Countries. Atlantic Economic Journal, (28)1: 83-92.

Fidrmuc, J. - Grozeza-Helmenstein, D. - Wörgötter, A. (1999): East-West intra-industry trade dynamics. Weltwirtschaftliches Archiv, (135)2: 333-346.

Fontagné, L. - Freudenberg, M. (1997): Intra-Industry Trade: Methodological Issues Reconsidered. CEPII Working Paper, No. 1997-01.

Fontagné, L. - Freudenberg, M. (2005): Disentangling Horizontal and Vertical Intra-Industry Trade. CEPII Working Paper, No. 2005-10.

Gabrisch, H. - Segnana, M. L. (2002): Why is trade between the European Union and the transition economies vertical? Discussion Paper, No. 7, Universitá degli studi di Trento, Dipartimento di Economia, Trento.

Gabrisch, H. - Szalai, K. (2002): The use of unit values in estimating trade-related capital flight. IWH Discussion Papers, No. 161.

Goh, Cl. - Smarzynska Javorcik, B. (2005): Trade protection and industry wage structure in Poland. NBER Working Paper, No. 11143. Cambridge, Mass. : National Bureau of Economic Research.

Greenaway, D. - Haynes, M. - Milner, C. (2002): Adjustment, employment characteristics and intra-industry trade. Weltwirtschaftliches Archiv, (138)2: 254-277.

Helpman, E. (1987): Imperfect competition and international trade: evidence from fourteen industrial countries. Journal of the Japanese and International Economies, 1: 62-81.

Hummels, D. - Levinsohn, J. (1995): Monopolistic competition and international trade: reconsidering the evidence. Quarterly Journal of Economics, 110: 799-836.

Krugman, P. (1986): A "technology gap" model of international trade. In: K. Jungenfelt - Hague, D. (eds.): Structural Adjustment in Advanced Economies. Basingstoke: Macmillan, pp. 35-48.

Landesmann, M. (1993): Industrial policy and the transition in East-Central Europe. WIIW Research Reports, No. 196. Vienna: Wiener Institut für Internationale Wirtschaftsvergleiche.

Landesmann, M. - Burgstaller, J. (1997): Vertical product differentiation in EU markets: the relative position of east European producers. WIIW Research Reports, No. 234. Vienna: Wiener Institut für Internationale Wirtschaftsvergleiche.

Loertscher, R. - Wolter, F. (1980): Determinants of intra-industry trade: among countries and across industries. Weltwirtschaftliches Archiv, (116)2: 280-293.

Lorentowicz, A. - Dalia M. - Raubold, A. (2005): Is human capital losing from outsourcing? Evidence for Austria and Poland. University of Munich: Discussion Paper, No. 76.

Martin-Montaner, J. - Orts Ríos, V. (2002)-: Vertical specialization and intra-industry trade. Weltwirtschaftliches Archiv 138 (2): 340-66.

Milanovic, B. (1998): Income, Inequality and Poverty during the Transition from Planned to Market Economy. World Bank, Washington, D C.

Milgram-Baleix, J. - Moro-Egido, A.I. (2006): Do endowments matter for vertical intra-industry trade with emerging countries? Empirical evidence. Universidad de Granada, Departamento de Teoria e Hiostroia Economica, THE Papers 06/10.

Rosati, D. (1999): Emerging trade patterns of transition countries: some observations from the analysis of unit values. MOCT-MOST, (8)2: 51-67.

Schott, Peter K. (2004): Across-Product versus Within-Product Specialization in International Trade. Quarterly Journal of Economics, (119)2: 647-678.

Thom, R. - McDowell, M. (1998): Trade Liberalisation and Adjustment: How Important is Intra-Industry Trade? Working Paper, No. 6, University College Dublin, School of Economics.

UNU/WIDER (2005): Inequality Database V 2.0a June (2005). Available at http://www.wider.unu.edu/wiid/wiidintroduction-2005-1.htm, (WIID2a). 
Vona, S. (1991): On the measurement of intra-industry trade: some further thoughts. Weltwirtschaftliches Archiv, (127)4: 678-700.

Zhang, J. - Witteloostuijn, A. V. - Zhou, C. (2005): Chinese bilateral intra-industry trade: a panel data study for 50 countries in the 1992-2001 period. Weltwirtschaftliches Archiv, (141)3: 510-541. 
Table 1

Descriptive statistics of REL-variables (420 observations); original values

\begin{tabular}{|c|c|c|c|}
\hline & \multicolumn{3}{|c|}{ RELGDPC (in Euro) $^{\mathrm{a}}$} \\
\hline & 1993 & 2000 & 2004 \\
\hline Mean & 9668 & 13123 & 13329 \\
\hline St.dev. & 3345 & 4388 & 4966 \\
\hline Highest value & 14993 & 20400 & 24100 \\
\hline \multirow[t]{3}{*}{ Lowest value } & 973 & 300 & 400 \\
\hline & \multicolumn{3}{|c|}{ RELTECH (shares) $^{b}$} \\
\hline & \multicolumn{3}{|c|}{$\mathrm{t}=1$ ("1993") $\quad \mathrm{t}=2(" 1997 ") \quad \mathrm{t}=3(" 2002 ")$} \\
\hline Mean & 0.058 & 0.050 & 0.050 \\
\hline Stand. Dev. & 0.043 & 0.038 & 0.036 \\
\hline Highest value & 0.174 & 0.161 & 0.172 \\
\hline \multirow[t]{3}{*}{ Lowest value } & 0.003 & 0.003 & 0.002 \\
\hline & \multicolumn{3}{|c|}{ RELINDIS $^{\mathrm{c}}$} \\
\hline & $\mathrm{t}=1(" 1993 ") \quad \mathrm{t}=$ & $\left.000^{\prime \prime}\right) \mathrm{t}=$ & 004") \\
\hline Mean & 19.132 & 19.019 & 16.406 \\
\hline Stand. Dev. & 12.039 & 12.837 & 14.249 \\
\hline Highest value & 37.990 & 47.345 & 48.078 \\
\hline lowest value & 0.590 & 0.590 & 0.205 \\
\hline
\end{tabular}

${ }^{a}$ Difference between EU country $\mathrm{j}$ and CEE country k; ${ }^{b}$ absolute difference of shares; ${ }^{\mathrm{c}}$ absolute difference in cumulated income shares.

Sources: Eurostat Online Database (2005b, 2006); UNU/WIDER (2005); author's calculations. 
Table 2

Vertical IIT regression results with TSLS

\begin{tabular}{|c|c|c|c|c|c|c|}
\hline & \multicolumn{2}{|c|}{ Pooled $^{\mathrm{a}}$} & \multicolumn{2}{|c|}{ Fixed effects $^{\mathrm{a}}$} & \multicolumn{2}{|c|}{ Random effects } \\
\hline & (1) & (2) & (3) & (4) & (5) & (6) \\
\hline \multicolumn{7}{|l|}{$\begin{array}{l}\text { Explanatory } \\
\text { variables }\end{array}$} \\
\hline Constant & $2.051^{* *}$ & $-1.918 * *$ & $-4.254 * * *$ & $1.306^{* * *}$ & -1.228 & $-1.2246 * * *$ \\
\hline RELGDPC & 0.004 & -- & $-0.069 * * *$ & -- & 0.003 & -- \\
\hline RELTECH & -- & $-0.010^{*}$ & -- & $0.006 * * *$ & -- & -0.003 \\
\hline RELINDIS & 0.009 & $-0.004 * * *$ & $0.001 * * *$ & $0.001 * * *$ & -0.000 & -0.000 \\
\hline MINSIZE & $0.065 * * *$ & $0.130 * * *$ & $-0.203 * * *$ & $0.194 * * *$ & $0.067 * * *$ & $0.069 * * *$ \\
\hline MAXSIZE & $0.044 * * *$ & $0.074 * * *$ & $0.566^{* * *}$ & $-0.246 * * *$ & $0.056^{* * *}$ & $0.061 * * *$ \\
\hline DISTANCE & $-0.424 * * *$ & 0.008 & -- & -- & -- & -- \\
\hline CUDUM & $-0.080 * *$ & $-0.177 * * *$ & -- & -- & -- & -- \\
\hline Adj. $R^{2}$ & 0.639 & 0.592 & 0.999 & 0.999 & 0.174 & 0.187 \\
\hline $\begin{array}{l}\text { Sum squared } \\
\text { res. }\end{array}$ & 15.784 & 8.339 & 0.961 & 0.909 & 6.018 & 5.980 \\
\hline $\begin{array}{l}\text { Chi-squared } \\
\text { stat. }^{\text {b }}\end{array}$ & & & -- & -- & 6.457 & $11.455^{* *}$ \\
\hline
\end{tabular}

${ }^{a}$ Cross-section weights. ${ }^{b}$ Hausmann-test. ${ }^{\mathrm{c}}$ Instruments: (1), 3), and (5): RELGDPC, RELGDPC(-1), MINSIZE(-1), MAXSIZE(-1), RELINDIS, RELINDIS(-1); (2), (4), and (6): RELTECH, RELTECH(-1), MINSIZE(-1), MAXSIZE(-1), RELINDIS, RELINDIS(-1); note that unproblematic regressors might instrument themselves.

$* * * 1 \%$ significance level, ** $5 \%$, * $10 \%$. 


\section{Table 3}

Horizontal IIT regression results with TSLS

Pooled $^{\mathrm{a}} \quad$ Fixed effects ${ }^{\mathrm{a}} \quad$ Random effects

(1)

(2)

(3)

(4)

(5)

(6)

\begin{tabular}{|c|c|c|c|c|c|c|}
\hline \multicolumn{7}{|l|}{$\begin{array}{l}\text { Explanatory } \\
\text { variables }\end{array}$} \\
\hline Constant & $0.907 * *$ & -0.077 & $3.668^{* * *}$ & $0.519^{* * *}$ & $-0.234 * * *$ & $-0.435^{* * *}$ \\
\hline RELGDPC & $-0.018 * * *$ & -- & $0.057 * * *$ & -- & $-0.017 * * *$ & -- \\
\hline RELTECH & -- & -0.004 & -- & $-0.006 * * *$ & -- & $-0.004 *$ \\
\hline RELINDIS & 0.000 & -0.000 & $0.001 * * *$ & $0.000 * * *$ & $-0.001 * *$ & $-0.000^{*}$ \\
\hline MINSIZE & $0.018 * * *$ & $0.030 * * *$ & $0.353 * * *$ & $0.109 * * *$ & $0.020^{* * *}$ & $0.025 * * *$ \\
\hline MAXSIZE & $0.009 * * *$ & $0.017 * * *$ & $-0.606^{* * *}$ & $-0.120 * * *$ & $0.018 * * *$ & $0.021 * * *$ \\
\hline DISTANCE & $-0.135 * * *$ & -0.048 & -- & -- & -- & -- \\
\hline CUDUM & $-0.037 * * *$ & -0.039 & -- & -- & -- & -- \\
\hline Adj. $\mathrm{R}^{2}$ & 0.564 & 0.587 & 0.979 & 0.993 & 0.215 & 0.176 \\
\hline $\begin{array}{l}\text { Sum squared } \\
\text { res. }\end{array}$ & 1.976 & 0.839 & 0.334 & 0.186 & 0.704 & 0.727 \\
\hline $\begin{array}{l}\text { Chi-squared } \\
\text { stat. }^{\text {b }}\end{array}$ & -- & -- & -- & -- & 5.742 & 4.378 \\
\hline
\end{tabular}




\section{Table A1}

Vertical IIT regressions with OLS

\begin{tabular}{|c|c|c|c|c|c|c|}
\hline \multirow{2}{*}{$\begin{array}{l}\text { Explanatory } \\
\text { variables }\end{array}$} & \multicolumn{2}{|c|}{ Pooled $^{\mathrm{a}}$} & \multicolumn{2}{|c|}{ Fixed effects ${ }^{\mathrm{a}}$} & \multicolumn{2}{|c|}{ Random effects } \\
\hline & (1) & (2) & (3) & (4) & (5) & (6) \\
\hline Constant & -0.004 & -0.045 & $-0.708^{* * *}$ & $--0.850^{* * *}$ & -- & -- \\
\hline RELGDPC & -0.007 & -- & $0.028 * *$ & -- & 0.002 & -- \\
\hline RELTECH & -- & 0.001 & -- & $0.007 * *$ & -- & 0.005 \\
\hline RELINDIS & $-0.001 * * *$ & $-0.001 * * *$ & $0.000^{*}$ & $0.003 *$ & -0.000 & -0.000 \\
\hline MINSIZE & $0.053 * * *$ & $0.053 * * *$ & $0.029 * * *$ & $0.022 * * *$ & $0.042 * * *$ & $0.041 * * *$ \\
\hline MAXSIZE & $0.039 * * *$ & $0.037 * * *$ & $0.027 * *$ & $0.058 * * *$ & $0.049 * * *$ & $0.047 * * *$ \\
\hline DISTANCE & $-0.103 * * *$ & -0.103 & -- & -- & -- & -- \\
\hline CUDUM & -0.008 & -0.001 & -- & -- & -- & -- \\
\hline Adj. $R^{2}$ & 0.731 & 0.727 & 0.894 & 0.888 & 0.227 & 0.229 \\
\hline $\begin{array}{l}\text { Sum squared } \\
\text { res. }\end{array}$ & 6.056 & 6.064 & 1.774 & 1.759 & -- & -- \\
\hline $\begin{array}{l}\text { Chi-squared } \\
\text { stat. }\end{array}$ & -- & -- & -- & -- & $20.818^{* * *}$ & $22.026 * * *$ \\
\hline
\end{tabular}

${ }^{\mathrm{a}}$ Cross-section weights. ${ }^{\mathrm{b}}$ Hausmann-test.

$* * * 1 \%$ significance level, ** $5 \%, * 10 \%$. 
Table A2

Horizontal IIT regressions with OLS

\begin{tabular}{|c|c|c|c|c|c|c|}
\hline \multirow{3}{*}{$\begin{array}{l}\text { Explanatory } \\
\text { variables }\end{array}$} & \multicolumn{6}{|c|}{ OLS } \\
\hline & \multicolumn{2}{|c|}{ Pooled $^{\mathrm{a}}$} & \multicolumn{2}{|c|}{ Fixed effects ${ }^{a}$} & \multicolumn{2}{|c|}{ Random effects } \\
\hline & (1) & (2) & (3) & (4) & (5) & (6) \\
\hline Constant & -0.006 & $-0.057 * * *$ & $-0.278 * * *$ & $-0.215^{* * *}$ & $-0.187 * * *$ & $-0.256 * * *$ \\
\hline RELGDPC & $-0.007 * * *$ & -- & $-0.027 * * *$ & -- & $-0.010 * *$ & -- \\
\hline RELTECH & -- & -0.000 & --- & $0.004 * * *$ & -- & 0.001 \\
\hline RELINDIS & -0.000 & $-0.000 * * *$ & $-0.000^{* * *}$ & $0.000^{*}$ & $-0.000^{* *}$ & $-0.000^{* *}$ \\
\hline MINSIZE & $0.011 * * *$ & $0.011 * * *$ & 0.000 & $0.003 * *$ & $0.013 * * *$ & $0.013 * * *$ \\
\hline MAXSIZE & $0.010 * * *$ & $0.001 * * *$ & $0.044 * * *$ & $0.014 * * *$ & $0.015 * * *$ & $0.013 * * *$ \\
\hline DISTANCE & $-0.018 * * *$ & $-0.018 * * *$ & -- & -- & -- & -- \\
\hline CUDUM & $0.005^{* *}$ & $0.001 * * *$ & -- & -- & -- & -- \\
\hline Adj. $R^{2}$ & 0.651 & 0.642 & 0.888 & 0.769 & 0.166 & 0.158 \\
\hline $\begin{array}{l}\text { Sum squared } \\
\text { res. }\end{array}$ & 0.844 & 0.850 & 0.448 & 0.456 & 0.904 & 0.914 \\
\hline $\begin{array}{l}\text { Chi-squared } \\
\text { stat. }^{\text {. }}\end{array}$ & -- & -- & -- & -- & $12.381 * *$ & $12.185^{* *}$ \\
\hline
\end{tabular}

${ }^{a}$ Cross-section weights. ${ }^{b}$ Hausmann-test.

$* * * 1 \%$ significance level, ** $5 \%, * 10 \%$. 


\section{Figure captions (plus sources!)}

Figure 1: Descriptive statistics of Grubel-Lloyd indices of of total intra-industry trade in EU trade with CEECs (1993 2000, 2004)

Source: Eurostat online database (2005a); authors calculations.

Figure 2: Descriptive statistics of percentage shares of vertical intra - industry EU trade flows in total intra-industry trade (Grubel-Lloyd indices 1993, 2000, 2004)

Source: Eurostat online database (2005a); author's calculation

Figure 3: Descriptive statistics of percentage shares of EU high-quality position in vertical intraindustry trade with CEECs (Grubel-Lloyd indices 1993, 2000, 2004)

Source: Eurostat online database (2005a); author's calculations.

\footnotetext{
${ }^{1}$ We selected those 10 countries that joined the EU in 2004 and 2007 respectively.

${ }^{2}$ Some recent papers disregard income distribution as VIIT determinant; see Díaz Mora 2002; Milgram-Baleix and Moro-Egido, 2006.

${ }^{3}$ The former study deals with the impact of cheap Eastern products on wages in Austria, the second one discusses the impact of trade liberalization on income distribution in Poland via more competition by higher quality varieties.

4 Diaz Moro (2002), and Milgram-Baleix and Moro-Egido (2006), disregard the income distribution variable, without discussing the possible consequences for the quality of estimation results.

${ }^{5}$ Flam - Helpman (1987, pp. 816-19) provide the graphical presentations for that cycle.

${ }^{6}$ In fact, trade liberalization started earlier, with the interim agreements with Poland, Hungary, and then Czechoslovakia in 1992. The liberalization advanced in a very asymmetric way. Therefore, we decided to take the customs union as a state of symmetric and complete trade liberalization.

${ }^{7}$ Assume $G D P_{k} / G D P_{j}$ to be the ratio illustrating the similarity of size of both countries $k$ and $j$, and which is $<1$ in the EU-CEEC framework. Then we can write as an empirical function: IIT $=\alpha \operatorname{lnGDP}{ }_{k}+\beta \operatorname{lnGDP}{ }_{\mathrm{j}}$, and expect a negative sign for $\beta$, hence for the vector of EU values. Since Loertscher and Wolter (1980, p. 283) most empirical studies, including that of Helpman (1987) have this empirical specification for the size-similarity variables.

${ }^{8}$ Data for Austria, Finland and Sweden are for 1995.

${ }^{9}$ Other studies report higher or lower values. The use of weighted or unweighted means and the disaggregation level makes the difference to them.
} 
${ }^{10}$ The GDP per capita of EU countries is higher than in CEECs in all bilateral cases; hence, we do not need to calculate absolute differences as in other research.

${ }^{11}$ An often used indicator for technology is based on R\&D expenditures and presented, for example, by the OECD (Basic Science and Technology Statistics). However, to obtain the R\&D capital stock, a calculation procedure with some critical assumptions (about depreciation ratios, for example) is required.

${ }^{12}$ Durkin and Krygier (2000) simply set the income of the lowest US quintile in purchasing power parity as the overlapping income class; an approach, which is not possible in the EU-CEE framework, for almost in no CEE country a decile exceeding the EU country's lowest decile could be found.

${ }^{13}$ For example, in the Polish-Greek case, the Polish GDP was higher than the Greek one.

${ }^{14}$ The Note that the Constant is the sum of all country FEs. FEs may be obtained from the author on request.

${ }^{15}$ One should mention here Milgram-Baleix and Moro-Egido (2006), who were surprised to receive a negative sign for the GDP per capita variable. It seems not to be satisfying to write that the result would be in , harmony with some other empirical studies'.

${ }^{16}$ For 1993, no data were available in 13 cases, which is 1.9 per cent of the entire 693 observations. Gaps were filled by extrapolating mean values from the remaining two entries (2000 and 2004).

${ }^{17}$ We disregard also the Aquino index, which corrects even for imbalances in the individual industries. See the critical review by Vona (1991) on calculating intra-industry indices. 